\title{
O AGRO É TECH, É POP, É TUDO: O (DES) VELAR DESSA REALIDADE ${ }^{1}$
}

Antônio Sidnei Ribeiro Cardoso ${ }^{2}$ Raimunda Áurea Dias de Sousa ${ }^{3}$ Leandro Cavalcanti Reis ${ }^{4}$

Resumo: Atualmente, o Brasil é "vendido" por meio da propaganda - "Agro é Pop", "Agro é tech", "Agro é Tudo", referindo-se a um país com diversidade na produção de alimentos. O setor do agronegócio se apresenta como símbolo de modernidade e eficiência, com domínio pleno de diferentes tecnologias. Com base nisso, o presente trabalho objetiva desvelar as contradições que se encontram veladas na palavra AGRO propagandeada como um negócio em que as grandes corporações, ao deterem o controle dos insumos, sementes e tecnologia utilizadas para um alcance multiescalar do produto produzido, disseminam a ideia de que é pop, ou seja, beneficia a todos. Assim, ele não pode ser pop, pois promove a concentração de terra, seguida da violência no campo; não pode ser tech, quando sua produção se sustenta no uso de agrotóxicos que, contraditoriamente, provoca doenças; não é tudo, uma vez que o alimento, condição básica de existência, é transformado em commodities e passa a ser concentrado por um pequeno número de empresas. Para alcançar o objetivo proposto utilizou-se como metodologia: leitura bibliográfica referente a temática, consulta a sites referentes ao conteúdo e coleta dos dados para análise quantitativa/qualitativa dos resultados.

Palavras-chave: Agronegócio. Agrotóxicos. Agricultura.

\section{AGRO IS TECH, IT'S POP, IT'S ALL: THE (DES) VELAR OF THAT REALITY}

Abstract: Currently, Brazil is "sold" through advertising - "Agro is pop"; Agro is tech", "Agro is all" - referring to a country with diversity in food production. The agribusiness sector presents itself as a symbol of modernity and efficiency, with full control of different technologies. On the basis of this, the present work aims at revealing the contradictions that are veiled in the AGRO word propagandized as a business in which large corporations, by controlling the inputs, seeds and technology used for a multiscale reach of the produced product, spread the idea of which it is pop, that is, it benefits to all. Thus, it can not be pop, because it promotes concentration of land, followed by violence in the field; can not be tech, when its production is sustained in the use of pesticides that, contradictorily, causes diseases; is not everything, since food, the basic condition of existence, is transformed into commodities and is now concentrated by a small number of companies. In order to reach the proposed objective, the following methodology was used: bibliographic reading referring to the theme, referring to content sites and data collection for quantitative / qualitative analysis of the results.

Keywords: Agribusiness. Pesticides. Agriculture. Foods. Advertising.

\footnotetext{
$1 \mathrm{O}$ artigo foi desenvolvido a partir da pesquisa - PIBIC - Programa Institucional de Bolsas de Iniciação Científica CNPq/UPE.

2 Universidade de Pernambuco - Campus Petrolina, Petrolina, Brasil, antoniosidney095@gmail.com, https://orcid.org/ 0000-0003-3815-7006

3 Universidade de Pernambuco - Campus Petrolina, Departamento de Geografia, Petrolina, Petrolina, Brasil, aurea.souza@upe.br, https://orcid.org/0000-0002-4646-4500

4 Universidade federal de Sergipe, Aracaju, Petrolina, Brasil, leandro_creis@hotmail.com, https://orcid.org/ 0000-0002-0109-6222
} 


\section{EL AGRO ES TECH, ES POP, ES TODO: EL (DES) VELAR DE ESTA REALIDAD}

Resumen: Actualmente, Brasil es "vendido" por medio de la propaganda - "Agro es Pop";"Agro es tech", "Agro es todo" - refiriéndose a un país con diversidad en la producción de alimentos. El sector del agronegocio se presenta como símbolo de modernidad y eficiencia, con dominio pleno de diferentes tecnologías. Con base en ello, el presente trabajo objetiva desvelar las contradicciones que se encuentran veladas en la palabra AGRO propagandada como un negocio en que las grandes corporaciones, al detener el control de los insumos, semillas y tecnología utilizadas para un alcance multiescalar del producto producido, diseminan la idea de que es pop, es decir, beneficia a todos. Así, él no puede ser pop, pues promueve la concentración de tierra, seguida de la violencia en el campo; no puede ser tech, cuando su producción se sustenta en el uso de agrotóxicos que, contradictoriamente, provoca enfermedades; no es todo, una vez que el alimento, condición básica de existencia, es transformado en commodities y pasa a ser concentrado por un pequeño número de empresas. Para alcanzar el objetivo propuesto se utilizó como metodología: lectura bibliográfica referente a la temática, consulta a sitios referentes al contenido y recolección de los datos para el análisis cuantitativo / cualitativo de los resultados.

Palabras clave: Agronegocios. Agrotóxicos. Agricultura. Comida. Publicidade.

\section{Introdução}

O espaço rural passou a ser vendido pela mídia como um produtor de riqueza para o mercado, tendo como ponto de partida a terra na condição de negócio. Nessa perspectiva, no Brasil, com as articulações entre grandes corporações e Estado partir dos anos de 1990, o agronegócio se expande e se apropria da terra e dos frutos dela, utilizando-se do discurso, que é o único modelo com capacidade de combater a fome e gerar emprego. A propaganda no intervalo dos noticiários na TV, das novelas ou das salas de cinema, repete com imagens coloridas o sucesso do agronegócio brasileiro: "Agro é Tehc", "Agro é Pop", "Agro é Tudo5". Será?

Com base nessa linha de raciocínio, tem-se percebido o uso crescente da tecnologia para a produção da fruticultura de alta qualidade em Petrolina - PE (ver mapa) com o intuito de garantir o abastecimento do mercado externo durante todo o ano, o que faz aumentar, significativamente o número de lojas especializadas em comercializar agrotóxicos, consequentemente, diminui consideravelmente a produção de alimentos. Por essa razão, questiona-se: Por que o Agro é propagandeado como tech, pop, tudo, quando em Petrolina-PE há intenso uso de agroquímicos para aumentar a produção com saída de mercado, contraditoriamente, diminui alimentos indispensáveis à vida humana, como feijão, mandioca etc.?

5 Frase utilizada pela Rede Globo de Televisão para propagandear o agronegócio como uma totalidade que se encontra em todos os lugares. 


\section{Mapa 01: Localização de Petrolina-PE}

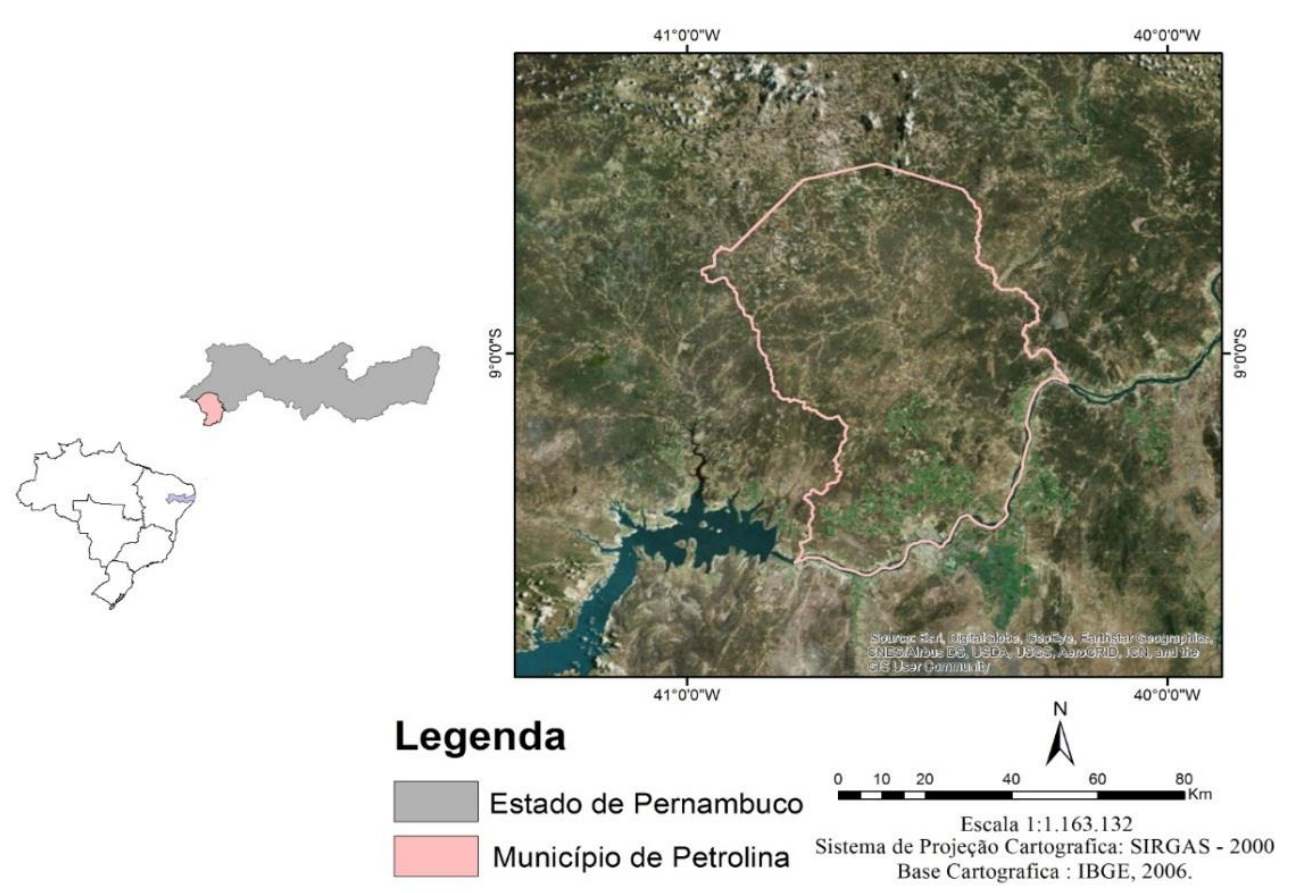

Elaboração: Grupo de Trabalho: Monitoramento Ambiental Geotecnologia e Ensino (GTMAGEO), 2019.

A necessidade de discutir a problemática proposta e alcançar o objetivo desejado conduziu-se a uma reflexão crítica das propagandas do Agro mostradas em horários de grande audiência como uma imposição de um modelo a ser seguindo no campo. Assim, a metodologia centra-se nos seguintes eixos de operacionalização: 1) a organização de uma pesquisa bibliográfica baseada em autores como: Martins (1982), Bombard (2012, 2016), Sousa (2013), Shanin (2008), Sauer (2008), Oliveira (2016); Em sites: CPT (Comissão Pastoral da Terra), MST (Movimento dos Trabalhadores Rurais Sem Terra), G1 AGRO (A Industria-Riqueza do Brasil); 2) A catalogação das imagens propagandeadas pelo Agro desde o primeiro semestre de 2016 ao último semestre de 2018, já que é por meio da mídia que se tenta disseminar a ideia de que ele é pop, tech e tudo, portanto, o centro do universo; 3) Os dados coletados a partir de análises quantitativa/qualitativa possibilitaram levantamento estatístico para a construção de um banco de dados vinculados à elaboração de gráficos, figuras e quadros, permitindo o desvelar da realidade, ou seja, o negócio que se encontra oculta em cada propaganda.

Por fim, o AGRO em Petrolina-PE, no Brasil e em países da América Latina é concentrador de terras e promotor da violência e de morte no campo. Para velar essa realidade, é necessária a propaganda com o intuito de conduzir as pessoas a acreditarem que ele é tudo, é tech e pop. 
Para fins didáticos, o artigo é subdivido em duas seções: na primeira: O agro: um negócio que se impõe como rentável? Mostra que o negócio está presente no agro em todas as etapas da produção privilegiando as grandes corporações; na segunda: O agro é tech, é pop, é tudo. Por que não poupa ninguém? Destaca que o agronegócio ao expandir-se no campo, não poupa ninguém, especialmente, quando promove o uso de agrotóxicos e trabalho escravo.

\section{O agro: um negócio que se impõe como rentável?}

O termo agronegócio foi utilizado em 1957, pela primeira vez, pelos professores John Davis e Ray Goldberg da Universidade Harvard, como agrobusiness $^{6}$ que, após a tradução para o português, ficou conhecido como agronegócio. Segundo Sousa (2013), o agronegócio é redefinido no discurso apologético do Estado como um conjunto de negócios relacionados à agricultura, cujo sentido designa, a princípio, um conjunto de ações ou transações comerciais comandadas pelo capital, na produção, industrialização e comercialização, que pode ser dividido em três partes: a) negócios agropecuários propriamente ditos (ou de "dentro da porteira"), que representam os produtores rurais, sejam eles pequenos médios ou grandes produtores; b) processo de integração horizontal (ou "da préporteira") os negócios da indústria e comércio de insumos, fertilizantes, agrotóxicos, máquinas, etc.; c) negócios à jusante (ou "pós-porteira"), que são aqueles negócios que compram os produtos agropecuários, os beneficiam, transportam-nos e vendem-nos para os consumidores finais. Nesse sentido, o termo refere-se a diferentes etapas da produção comandada pelo agronegócio que compreende a produção, o processamento, o armazenamento e a distribuição.

O discurso do agronegócio como modelo de agricultura a ser seguido centrase no uso das tecnologias como forma de acabar com a fome mundial e é nos anos de 1990 que ele chega ao Brasil, evidenciando a superioridade de uma agricultura voltada para o negócio em detrimento da agricultura para o trabalho, para a vida.

Segundo Bombardi (2016), o agronegócio não se encontra vinculado ao valor uso e, sim, somente a valor de troca. Nesse sentido, retira-se o foco da soberania e da segurança alimentar, dando espaço para o negócio quando o alimento perde a dimensão da garantia da sobrevivência humana e se transforma em commodities ${ }^{7}$.

\footnotetext{
${ }^{6}$ A soma total das operações de produção e distribuição de suprimentos agrícolas; as operações de produção nas unidades agrícolas; e o armazenamento, processamento e distribuição dos produtos agrícolas e itens produzidos com eles (DAVIS \& GOLDBERG, 1957).

${ }_{7}$ Qualquer produto originário de atividade agropecuária, florestal ou pesqueira ou qualquer mineral em sua forma natural ou que tenha passado por processamento costumeiramente requerido para
} 
Para a autora, os alimentos têm duas dimensões: 1) a transformação em combustível, ou seja, alguns dos cultivares que há séculos foram destinados à alimentação humana, têm-se tornado "massa" para a produção de energia, dentre eles, destaca-se principalmente a cana, o milho e a soja; 2) commodities, como é o caso da soja. Esses cultivos - dissociados do sentido de alimentação - têm sido feitos por meio do arcaico binômio "latifúndio- monocultura".

Conforme Martins (1982), a agricultura voltada para negócio é aquela que, quando o capital se apropria da terra, a mesma transforma em terra de exploração da força de trabalho alheia. O intuito é somente o lucro daquilo que a terra pode proporcionar

Assim, o agronegócio, na condição de agricultura moderna, deixa de ser somente "primário", ou seja, começa nos insumos, passa pela agropecuária e termina na forma de comida, bebida, roupas, energia, plástico etc., considerando-se, com isso, rentabilidade. Contudo, para a materialização desse modelo, há uma necessidade de grandes propriedades que são apropriadas por empresas capitalistas cuja finalidade é apropriação dos frutos da terra.

Nessa perspectiva, enquanto sistema dinâmico, o capital tenta suprimir qualquer unidade que impeça a multiplicação da riqueza material, como, por exemplo, a agricultura familiar camponesa, e cria outras unidades que contribuam com a produção/reprodução dessa riqueza para ele, por meio da ciência-técnica, tecnologia-tempo e trabalho que interagem entre eles, como estratégia para garantir retorno rápido aos investimentos realizados pelos capitalistas.

Seguindo essa linha de raciocínio, é possível ver o negócio contido no Agro quando há:

a) perdão das dívidas dos ruralistas pelo Governo;

[...] o presidente da Câmara dos Deputados, Rodrigo Maia (DEM-RJ), prometeu à bancada ruralista, uma das mais poderosas no Congresso, que vai trabalhar pelo perdão integral das dívidas de produtores rurais junto ao Funrural, espécie de contribuição previdenciária do setor. Um projeto de lei que extingue o débito, que soma cerca de $R \$ 17$ bilhões. (ESTADÃO, 2018). ${ }^{8}$

b) na proibição de produtos orgânicos em supermercado,

prepará-lo para comercialização em volume substancial no comércio internacional (Delgado, 2005 p. 128).

${ }^{8}$ Disponível em: <https://economia.estadao.com.br/noticias/geral,maia-promete-a-ruralistas-quetrabalhara-por-perdao-na-divida-com-funrural,70002264758> Acesso em 21/11/ 2018. 
No dia 15 de junho de 2018, a Comissão de Agricultura, Pecuária, Abastecimento e Desenvolvimento Rural aprovou um projeto que prevê a proibição de venda de orgânicos em estabelecimentos como supermercados, por exemplo. De autoria do deputado federal Edinho $\mathrm{Bez}$ (MDB/SC), o projeto de lei no 4576/16 quer que esse tipo de produto seja vendido apenas em feiras livres ou pelos próprios produtores, em propriedades particulares. Segundo a justificativa, a ideia é combater produtos fraudulentos. (METRO JORNAL, 2018). ${ }^{9}$

c) liberação de agrotóxicos nocivos à vida humana. "O Projeto de Lei 6299/2002, mais conhecido como "PL do Veneno", que propõe flexibilizar o uso e registro dos agrotóxicos no país, desconsidera todo e qualquer impacto na saúde, no meio ambiente e na economia". (FIOCRUZ, 2018) ${ }^{10}$.

Nessa perspectiva, o negócio rentável para a indústria, em detrimento da agricultura familiar camponesa, impede o agro de ser pop, de ser tudo, já que é um grupo muito diminuto da população que se beneficia, enquanto aqueles que, de fato, vivem no campo, muitas vezes, chegam ao limite da sobrevivência humana.

\section{O agro é tech, é pop, é tudo. Por que não poupa ninguém?}

Desde 2016, a propaganda no intervalo dos noticiários na TV, das novelas ou das salas de cinema repete, com imagens coloridas, o sucesso do agronegócio brasileiro por meio do slogan o agro é pop, o agro é tech, o agro é tudo - a indústria e a riqueza do Brasil. (GLASS E SANTOS, 2018). A repetição tem por finalidade criar empatia e confiança da população, apresentando que todos os setores econômicos - primário, secundário e terciário - são absorvidos pelo agronegócio e somente ele é capaz de gerar riqueza, empregar as pessoas e garantir a produção, inclusive dos alimentos indispensáveis à vida humana.

Conforme o banco de imagens que seguem, percebe-se como o agronegócio tem se utilizado da mídia para firmar uma campanha amparada por grupos empresariais - Bancada Ruralista e Rede Globo, de um modelo de agricultura rentável e, por essa razão, necessita concentrar terra.

\footnotetext{
9Disponível em: <https://www.metrojornal.com.br/foco/2018/07/03/venda-de-produtos-organicos-podeser-proibida-em-mercados-entenda.html acesso em 20/11/ 2018> Acesso em 21/11/ 2018.

10 Disponível em: <https://agencia.fiocruz.br/pl-do-veneno-desconsidera-impactos-na-saude-e-meioambiente> Acesso em 21/ 11/2018.
} 
Figura 01: Propagandas de 2016

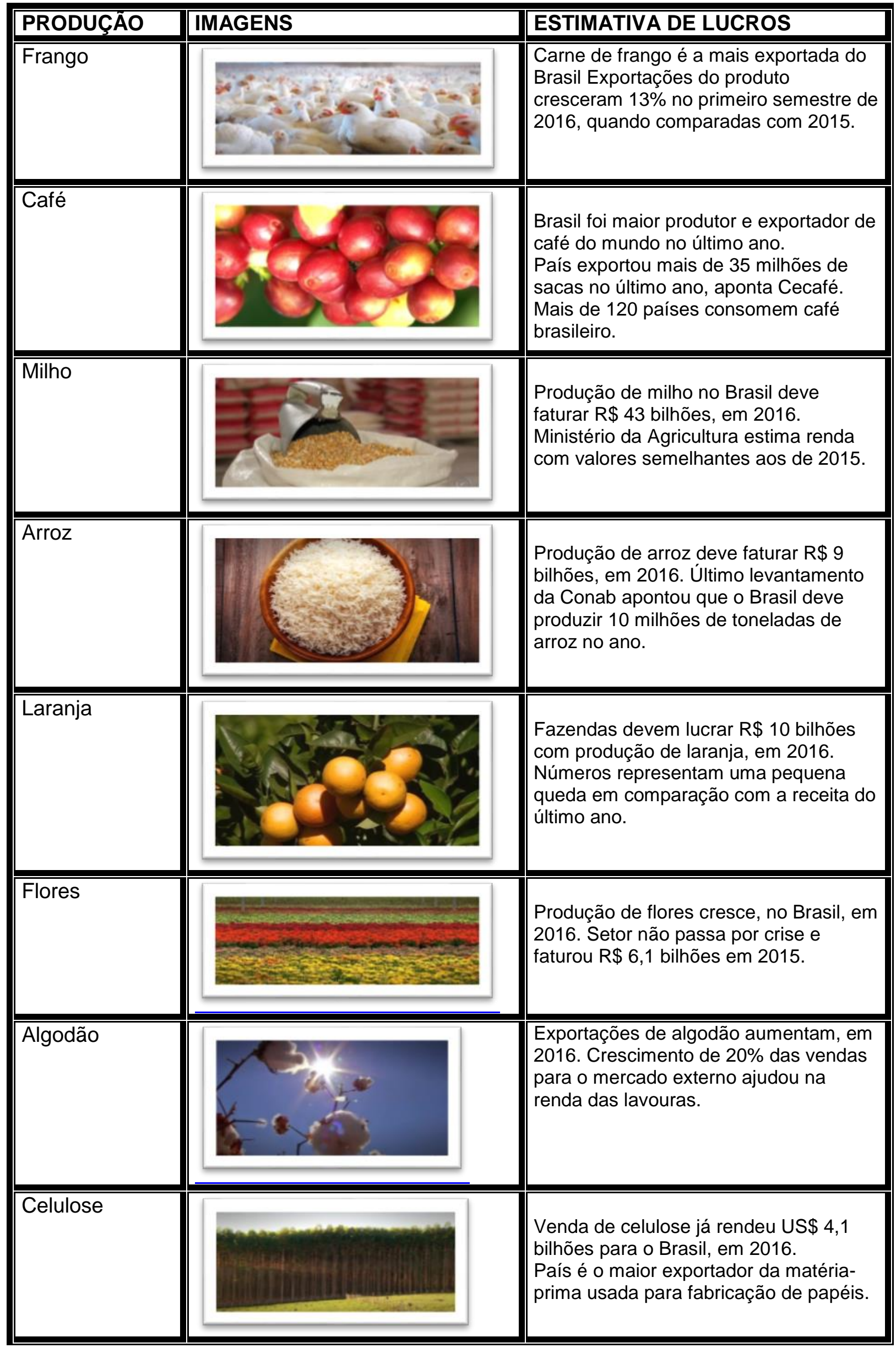




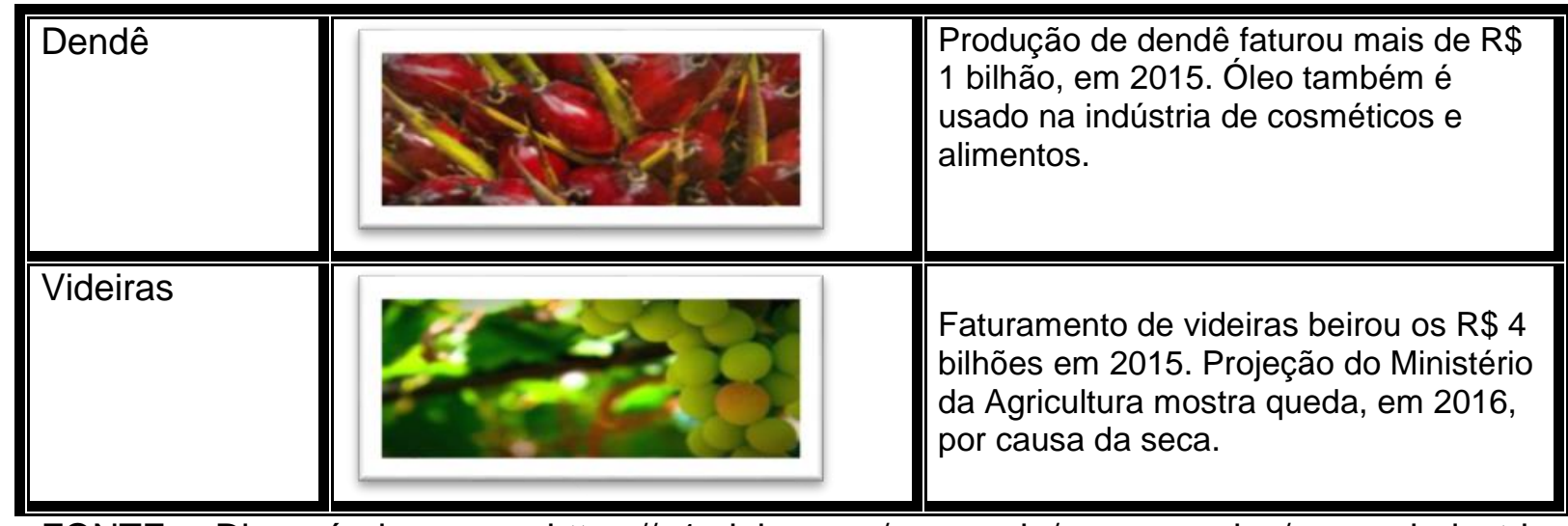

FONTE: Disponível em: <https://g1.globo.com/economia/agronegocios/agro-a-industriariqueza-do-brasil/>. Acesso em: 04/ 03/2018 Elaboração: (CARDOSO, A. S. R -2018)

Figura 02: Propagandas de 2017

\begin{tabular}{|c|c|c|}
\hline PRODUÇÃO & IMAGENS & ESTIMATIVA DE LUCRO \\
\hline $\begin{array}{l}\text { Suco integral } \\
\text { de Uva }\end{array}$ & & $\begin{array}{l}\text { Crescimento da venda de sucos de uva } \\
\text { integral ajuda o setor. } \\
\text { A venda de sucos integrais cresceu } 31 \% \\
\text { no último ano no Brasil. }\end{array}$ \\
\hline $\begin{array}{l}\text { Agricultura } \\
\text { familiar }\end{array}$ & & $\begin{array}{l}\text { Agronegócio brasileiro emprega } 19 \\
\text { milhões de pessoas. Setor que mais } \\
\text { emprega é o da agricultura familiar com } \\
11,5 \text { milhões de trabalhadores. }\end{array}$ \\
\hline Peixe Tilápia & & $\begin{array}{l}\text { Criação de peixes no Brasil cresce } 10 \% \text {, } \\
\text { em } 2016 \text {. Faturamento no ano foi de } R \$ \\
4,5 \text { bilhões. Tilápia é o tipo de peixe mais } \\
\text { produzido no Brasil. Produção do peixe } \\
\text { fica concentrada em quatro estados: } \\
\text { Paraná, São Paulo, Ceará e Santa } \\
\text { Catarina. }\end{array}$ \\
\hline$\overline{\text { Maçã }}$ & & $\begin{array}{l}\text { Produção de maçãs tem aumento de } \\
11 \% \text { no faturamento, em } 2016 . \\
\text { Tipos da fruta mais produzidos no Brasil } \\
\text { são Fuji e Gala. }\end{array}$ \\
\hline Feijão & & $\begin{array}{l}\text { Produção de feijão aumenta e } \\
\text { faturamento é de } \mathrm{R} \$ 9 \text { bilhões, em } 2016 \text {. } \\
\text { Último ano fechou com } 9 \% \text { de aumento } \\
\text { no faturamento do grão no Brasil. }\end{array}$ \\
\hline
\end{tabular}




\begin{tabular}{|c|c|}
\hline Banana & $\begin{array}{l}\text { Banana é a fruta mais consumida no } \\
\text { Brasil. Produção da fruta faturou } \mathrm{R} \$ 14 \\
\text { bilhões, em } 2016 \text {. } \\
\text { Faturamento com produção de banana } \\
\text { deve crescer em } 2017 \text {. Ministério da } \\
\text { Agricultura acredita que produção da } \\
\text { fruta pode faturar } \mathrm{R} \$ 16 \text { bilhões no ano. }\end{array}$ \\
\hline Soja & $\begin{array}{l}\text { Brasil deve ter safra recorde de soja. A } \\
\text { última previsão do IBGE fala em } 107 \\
\text { milhões de toneladas, aumento de } 11 \% \\
\text { em relação a } 2016 .\end{array}$ \\
\hline $\begin{array}{l}\text { Produção da } \\
\text { Agricultura } \\
\text { familiar }\end{array}$ & $\begin{array}{l}\text { Agricultura familiar é responsável por } \\
36 \% \text { da riqueza produzida no campo. De } \\
\text { acordo com o senso agropecuário de } \\
2006 \text {, ela constitui a base econômica de } \\
90 \% \text { dos municípios brasileiros com até } \\
20 \text { mil habitantes. }\end{array}$ \\
\hline Cacau & $\begin{array}{l}\text { Produção de cacau cresce, no Brasil em } \\
2017 \text {. Bahia é o estado que mais produz } \\
\text { o fruto, sendo responsável por } 54 \% \text { da } \\
\text { safra. Produção de cacau ajuda indústria } \\
\text { de balas e doces no Brasil. Chocolate, } \\
\text { vindo das sementes do fruto, entra em } \\
56 \% \text { da produção industrial de doces do } \\
\text { país. }\end{array}$ \\
\hline Cana & $\begin{array}{l}\text { Produção de cana no Brasil aumenta em } \\
2017 . \\
\text { Segundo Conab, produção deve chegar a } \\
694 \text { milhões de toneladas. }\end{array}$ \\
\hline Melão & $\begin{array}{l}\text { Nordeste é região do país que mais } \\
\text { produz melão. } \\
\text { Cerca de } 80 \text { mil pessoas são } \\
\text { empregadas na cultura da fruta na } \\
\text { região. }\end{array}$ \\
\hline \begin{tabular}{|l} 
Malha de \\
transportes
\end{tabular} & $\begin{array}{l}\text { Indústria agrícola depende de malha de } \\
\text { transportes para seu sucesso. } \\
\text { Integração entre produção e consumidor } \\
\text { é feita com ajuda de diferentes tipos de } \\
\text { transporte. }\end{array}$ \\
\hline
\end{tabular}




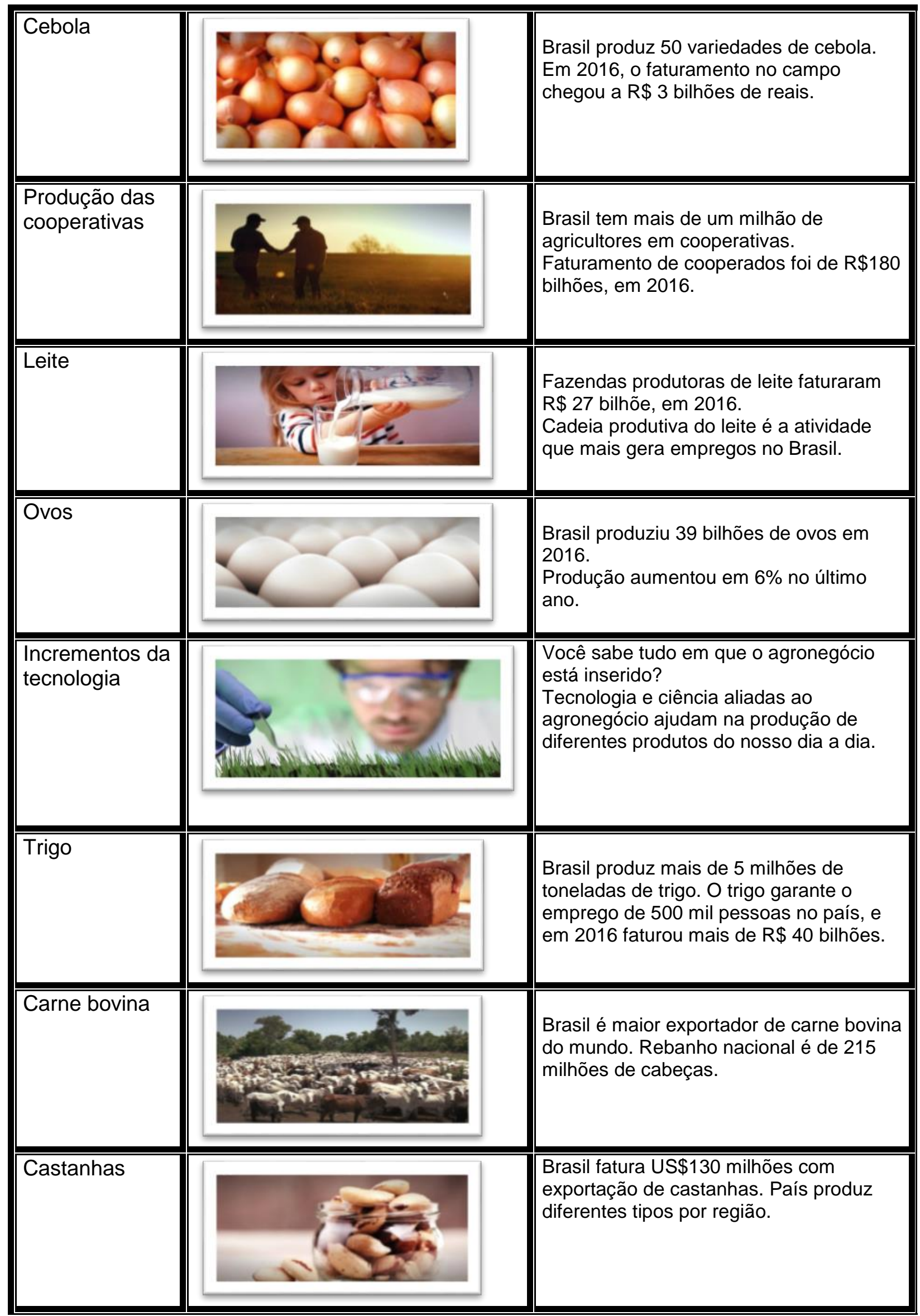




\begin{tabular}{|l||l|l|l||}
\hline $\begin{array}{l}\text { Produtos } \\
\text { orgânicos }\end{array}$ & $\begin{array}{l}\text { Mercado de produtos orgânicos cresce } \\
\text { no Brasil. } \\
\text { Em 2016, o mercado interno faturou } \mathrm{R} \$ 3 \\
\text { bilhões. }\end{array}$ \\
\hline \hline Ovelha & & $\begin{array}{l}\text { Brasil tem rebanho com 18 milhões de } \\
\text { ovelhas. Animais são usados na } \\
\text { produção de lã, carne e leite. }\end{array}$ \\
\hline \hline Cogumelo & & $\begin{array}{l}\text { Champignon é o cogumelo mais cultivado } \\
\text { no Brasil. } \\
\text { País tem perto de mil produtores de } \\
\text { cogumelo atualmente. }\end{array}$ \\
\hline
\end{tabular}

Fonte: Disponível em: https://g1.globo.com/economia/agronegocios/agro-a-industria-riquezado-brasil. Acesso em: 10/ 03/2018 Elaboração: CARDOSO, A. S. R.

Figura 03: Propagandas 2018

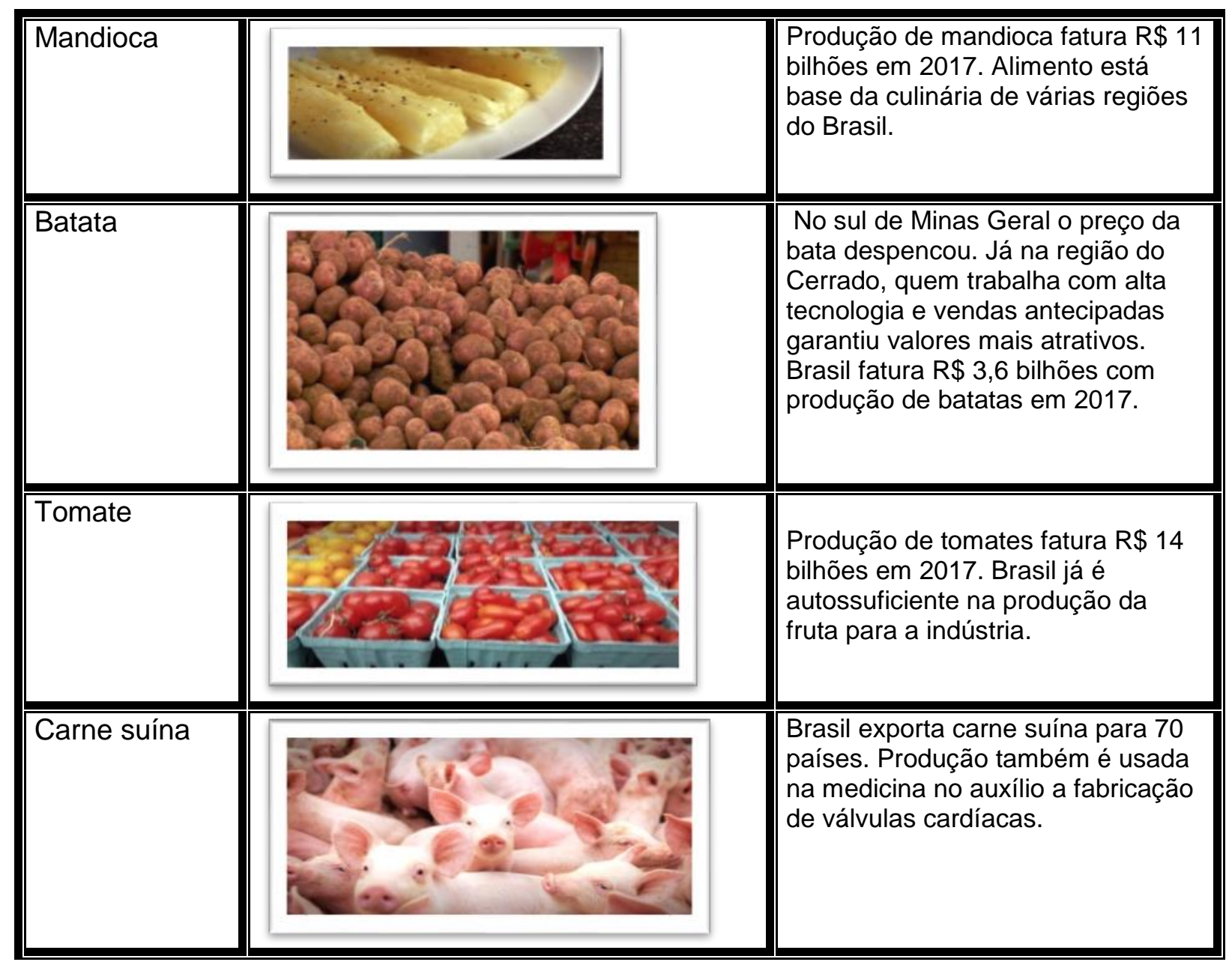




\begin{tabular}{|c|c|}
\hline $\begin{array}{l}\text { Presença } \\
\text { feminina no } \\
\text { campo }\end{array}$ & $\begin{array}{l}\text { Veterinárias, agricultoras, } \\
\text { pesquisadoras, presença feminina é } \\
\text { cada vez maior no campo. Nas } \\
\text { fazendas, há mais mulheres com } \\
\text { ensino superior do que homens. }\end{array}$ \\
\hline \begin{tabular}{|l}
$\begin{array}{l}\text { Consumo da } \\
\text { agua }\end{array}$ \\
\end{tabular} & $\begin{array}{l}\text { Setor agrícola é o maior } \\
\text { consumidor de água no Brasil. } \\
\text { Agricultores produzem água e } \\
\text { ajudam a conservar nascentes em } \\
\text { fazendas. }\end{array}$ \\
\hline Abelha & $\begin{array}{l}\text { Abelhas ajudam indústrias de } \\
\text { alimentos, beleza e farmacêutica. } \\
\text { As abelhas são os únicos insetos } \\
\text { que produzem alimentos que são } \\
\text { consumidos pelos humanos. }\end{array}$ \\
\hline Búfalo & $\begin{array}{l}\text { Brasil tem o maior rebanho de } \\
\text { búfalos do Ocidente. Quatro raças } \\
\text { estão espalhadas pelo país, } \\
\text { principalmente na Amazônia. }\end{array}$ \\
\hline Seringueira & $\begin{array}{l}\text { Indústria brasileira da borracha } \\
\text { emprega } 80 \text { mil pessoas. Os } \\
\text { seringais no Brasil renderam, no ano } \\
\text { passado, } \mathrm{R} \$ 346 \text { milhões. }\end{array}$ \\
\hline Coqueirais & $\begin{array}{l}\text { Trazida pelos portugueses, indústria } \\
\text { do coco fatura mais de } \mathrm{R} \$ 1 \text { bi por } \\
\text { ano. Os coqueirais empregam } 700 \\
\text { mil pessoas e ocupam } 230 \text { mil } \\
\text { hectares em todo o país. }\end{array}$ \\
\hline $\begin{array}{l}\text { Agronegócio } \\
\text { Brasileiro }\end{array}$ & \begin{tabular}{|l} 
Você conhece o agronegócio \\
brasileiro? Tecnologia e ciência \\
ajudam na produção de diferentes \\
produtos do nosso dia a dia.
\end{tabular} \\
\hline Etanol & $\begin{array}{l}\text { Campo produz energia para } \\
\text { diferentes atividades no Brasil. Em } \\
\text { 2017, usinas produziram } 27 \text { bilhões } \\
\text { de litros de etanol vindos da cana de } \\
\text { açúcar. }\end{array}$ \\
\hline
\end{tabular}




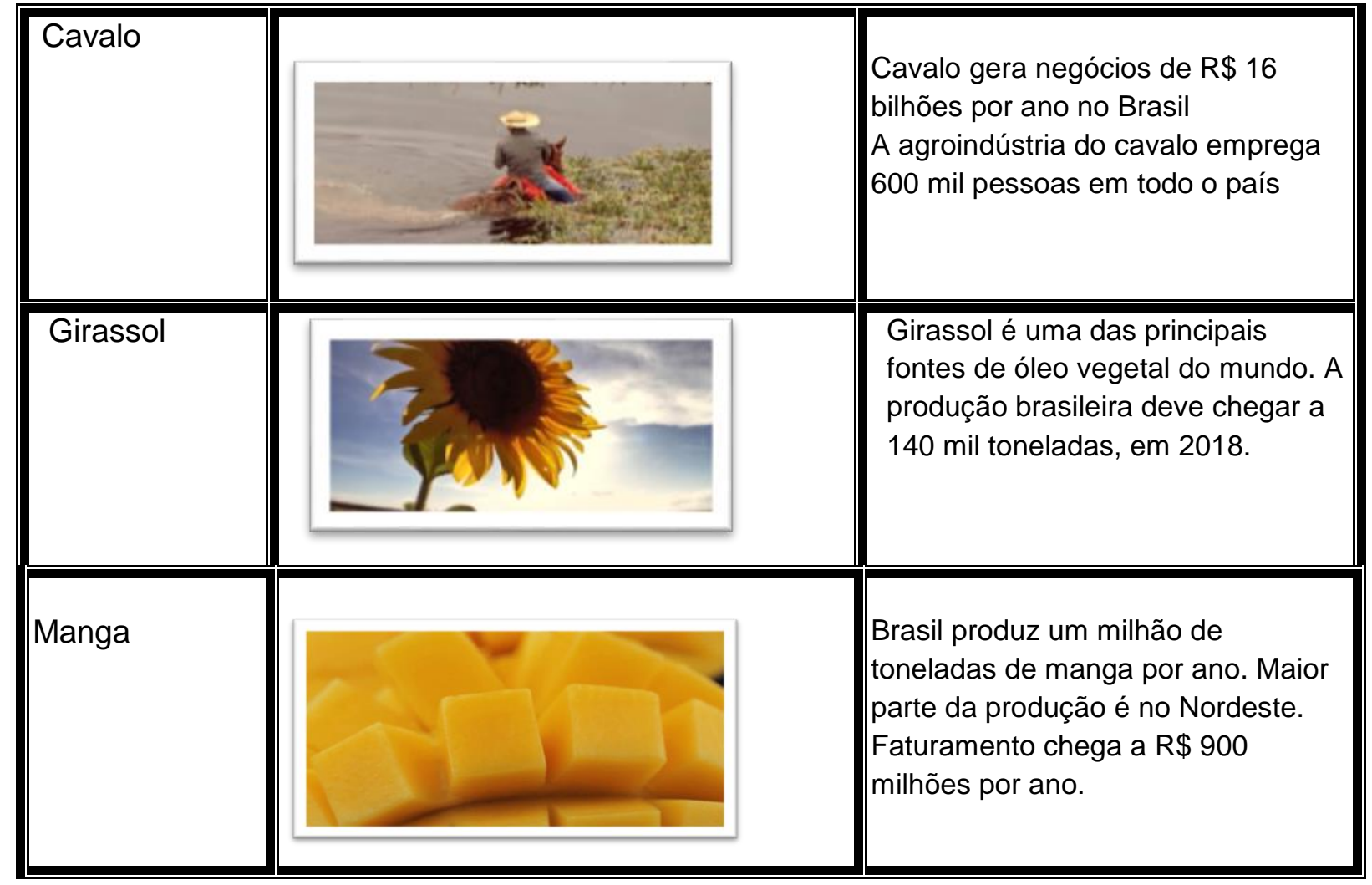

Fonte: Disponível em: https://g1.globo.com/economia/agronegocios/agro-a-industria-riquezado-brasil/ > . Acesso em 09/ 12/2018.

Nas imagens, explicita-se o faturamento obtido pelo agronegócio (ver gráfico 01 a seguir) como se tudo que há no campo fosse absorvido por ele, incluindo a agricultura familiar e camponesa. Esta resiste a esse modelo porque tem uma outra lógica - a sobrevivência da família e não absorver o mercado. 


\section{Gráfico 01: Exportação do agronegócio}

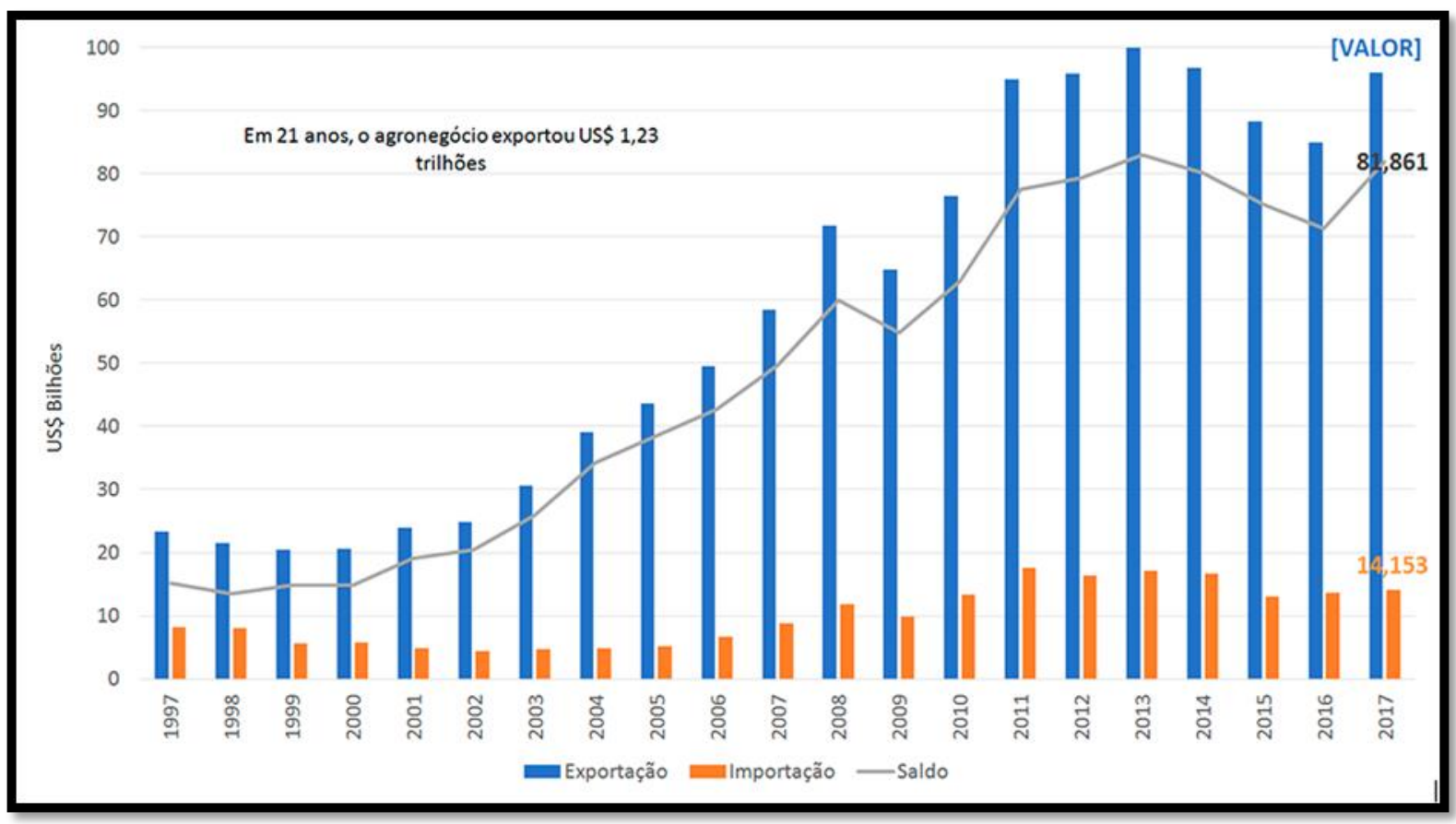

Fonte: AgroStat a partir dos dados da SECEX/MDIC. Disponível em: https://www.embrapa.br/olhares-para-2030/riscos-na-agricultura/-

/asset_publisher/SNN1QE9zUPS2/content/odilson-luiz-ribeiro-e-silva?inheritRedirect=true. Acesso em: 01/06/2018.

Ao observar o gráfico, é inquestionável a produção da riqueza e o que ele gerou de superávit na balança comercial brasileira em 2017 - US\$ 66 bilhões. Porém, quando se tem base da realidade do campo brasileiro e de Petrolina-PE, verifica-se que essa é mais complexa que os modelos e mais difícil de aprender devidamente. De acordo com Shanin (2008, p.34), "isso não significa que os modelos são inúteis. Mas, tratar modelo como se fosse a realidade é inútil e perigoso".

Quanto ao modelo do agronegócio de apropriação do campo, é possível apreender que ele não pode ser:

1. Pop - pois promove a concentração de terra seguida da violência no campo. No Brasil, dados preliminares do censo agro, mostram que de 2006, havia estabelecimentos com mais de mil hectares controlando $45 \%$ das terras; já em 2017 são 47,5\%. Em relação à quantidade de estabelecimentos: em 2006 eram 5.072.152 estabelecimentos; em 2017 são 5.175.636 5. Ainda, eles ocupam uma área maior: antes, eram 333 milhões de hectares; hoje são 350 milhões. Desse total, mais de 16 milhões de hectares estão concentrados nos grandes estabelecimentos, enquanto os menores, que têm até dez hectares, ocupam apenas $2,3 \%$. Com isso percebem-se, também, os investimentos no 
agronegócio reiterando ainda mais a impopularidade em que há aumento de espaço para os grandes latifúndios e perda agricultura familiar, de acordo com o gráfico 02 a baixo.

\section{Gráfico 02: Investimos na agricultura empresarial e agricultura familiar entre os anos de 2002 a 2017}

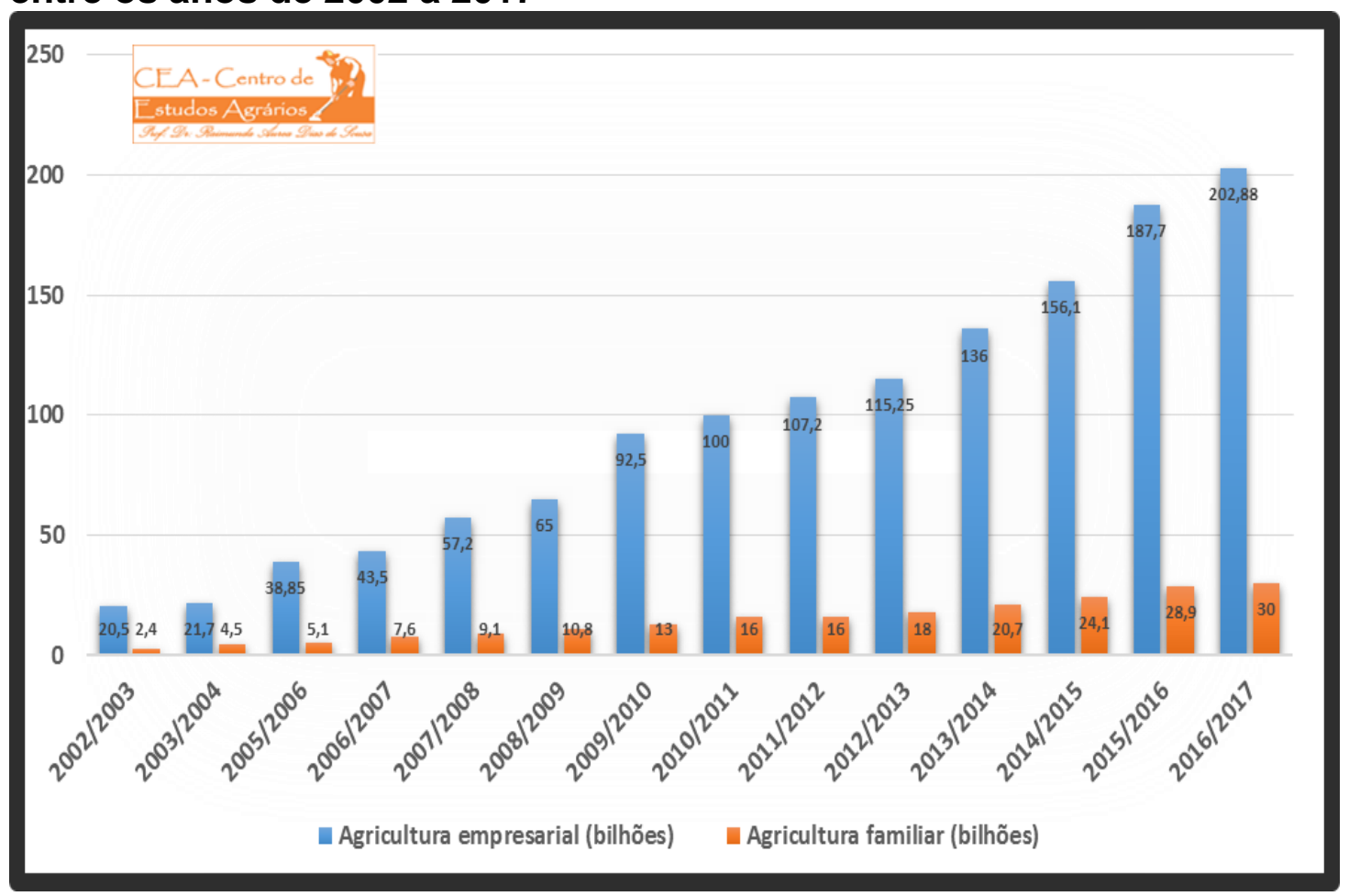

Fonte: Empresarial (Planos agrícolas e pecuários) - Familiar Plano Safra 2017: Disponível em: <http://www.mda.gov.br/sitemda/sites/sitemda/files/user_img_1684/3Baixa_Car tilha_Plano_Safra_2017.pdf. Acesso em: 13.12.2018.

Pelo gráfico 02, evidencia a forma como os investimentos são destinados ao agronegócio em detrimento à agricultura familiar. Sobre isso, Sauer (2008) afirma que, de um lado, uma enorme quantidade de terra que, em muitos casos, é subutilizada ou não utilizada, e articuladamente na mão de poucos, e de outro lado, uma massa de trabalhadores e trabalhadoras excluídos do acesso a terra, ou, até mesmo, com pouca terra ou terra de baixa qualidade, reiterando que essa exclusão é o lado mais perverso da concentração fundiária. Fica claro que a concentração da terra deixa evidente a impopularidade desse modelo centralizador.

Já em Petrolina, a partir de 1968, com a chegada dos perímetros irrigados, a terra passa a ser apropriada como negócio, conforme gráfico. 


\section{Gráfico 03: Área apropriada para irrigação - agronegócio}

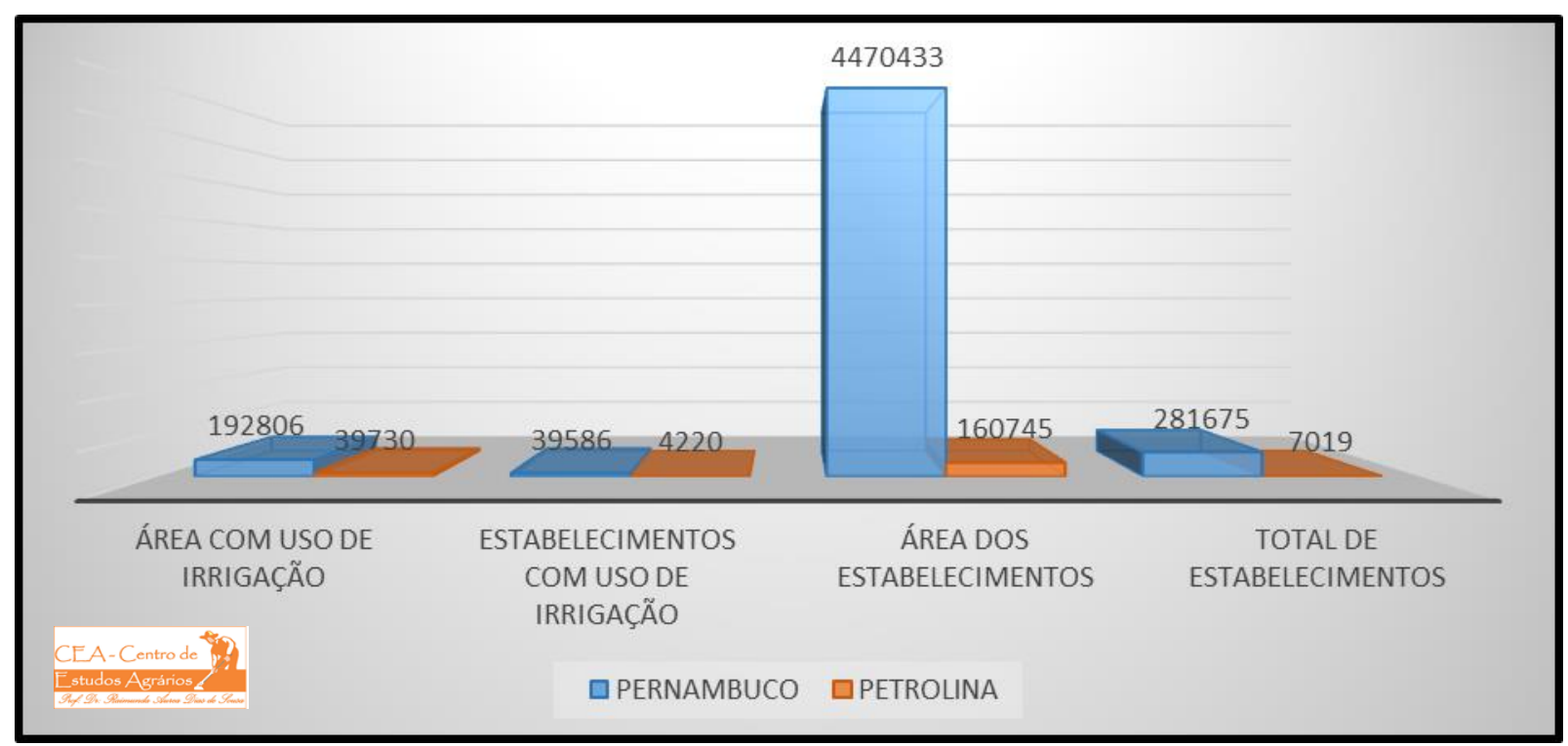

Fonte: Censo Agropecuário 2017 - Dados preliminares.

O agronegócio tem maior quantidade de terra para o cultivo irrigado no município de Petrolina. No gráfico é perceptível que Petrolina-PE concentra aproximadamente $3,5 \%$ da área dos estabelecimentos do estado de Pernambuco e 2,4\% dos estabelecimentos, já quando se refere à área irrigada, o município concentra cerca de $20,6 \%$ da área irrigada e $10,6 \%$ do total de estabelecimentos do estado que faz uso de irrigação. Assim, Petrolina-PE concentra um percentual significativo da área e dos estabelecimentos com uso de irrigação, destacando-se dessa forma como importante Polo do agronegócio da fruticultura irrigada.

Sendo concentradores, os conflitos no campo são inevitaveis, pois, de um lado, estão aqueles que utilizam a terra para negócio e do outro os que buscam, na terra, o trabalho, a vida. Somente, em 2017, foram 71 camponeses brutalmente assassinados, distribuidos nos seguintes estados. 


\section{Gráfico 04: Assassinatos no campo nos principais estados}

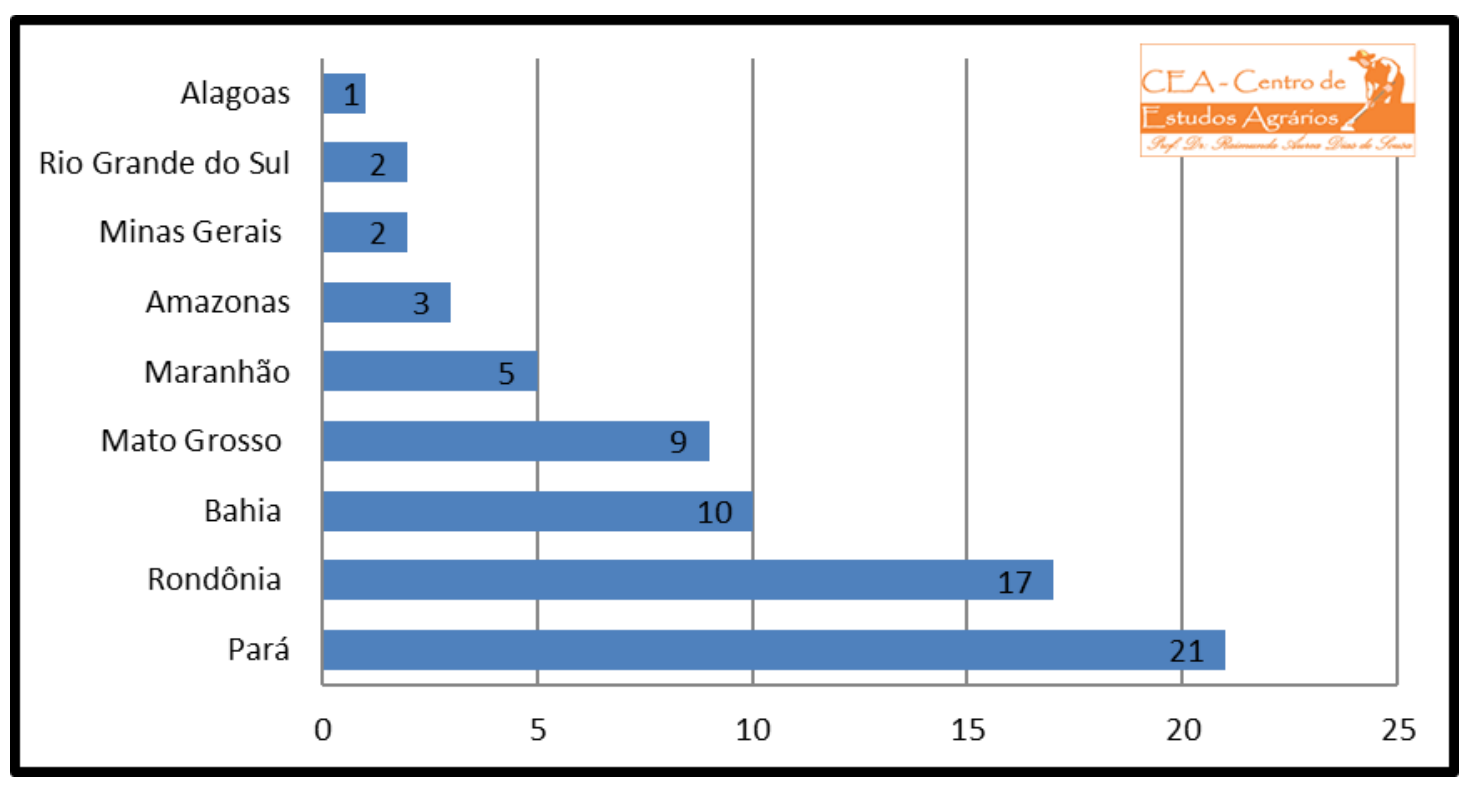

FONTE: $\quad<$ https://www.cptnacional.org.br/component/jdownloads/send/60-dados2017/14074-assassinatos-conflitos-no-campo-2017-cpt-assessoria-decomunicacao? Itemid=0.>. Acesso em: 01/09/2018 Elaborado: (CARDOSO, A. S. R.2018).

Em 2017, foram mais de 70 mortes no campo. Assim, quanto maior a concentração da terra, mais os conflitos aparecem no campo, tornando-se ainda mais evidentes, porque aumentam a diferença entre as classes.

2. Tech - uma das tecnologias se sustenta no uso de agrotóxicos para garantir a produção rápida; porém, contraditoriamente, provoca doenças seguidas de morte. Em Petrolina-PE, o gráfico 05 evidencia a intensidade do uso de agrotóxicos na agricultura, especialmente, na fruticultura. 


\section{Gráfico 05: Percentual dos estabelecimentos que faz uso de agrotóxico - \\ Petrolina/Pernambuco}

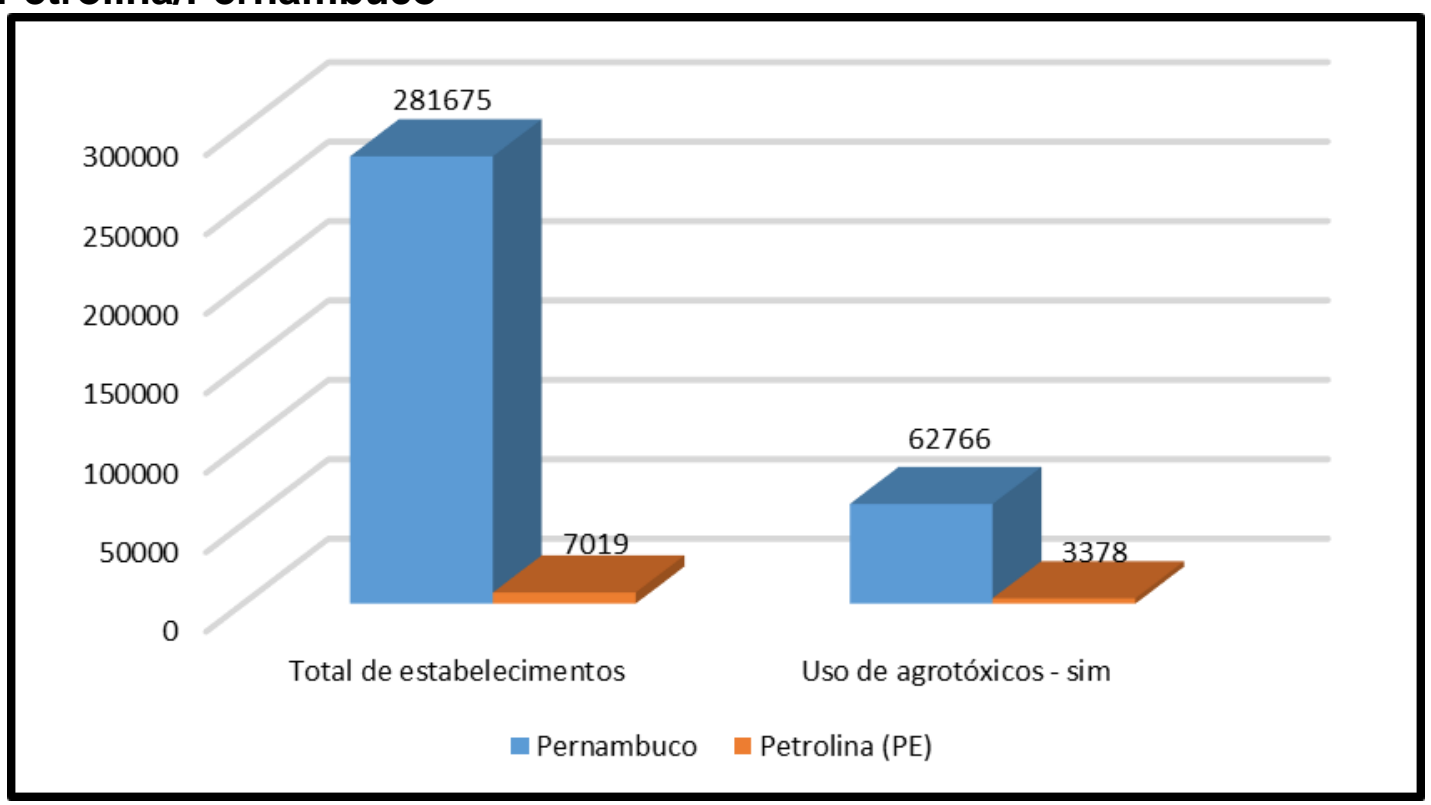

Fonte: Censo Agropecuário 2018 - Dados preliminares.

Percebe-se no gráfico 05, o estado de Pernambuco, declararam usar agrotóxico cerca de $22,2 \%$ dos estabelecimentos enquanto no município de Petrolina-PE 48,1\%, ou seja, enquanto no estado de Pernambuco 1 em cada 5 faz uso de agrotóxicos, no município de Petrolina quase a metade utiliza. E isso ocorre, justamente, naqueles conhecidos por serem "celeiros" dos produtos do agronegócio (BOMBARDI 2012). Como Petrolina se destaca na produção de uva e manga, consequentemente, o uso dos agrotóxicos é utilizado em larga escala.

Quando se fala de tecnologia, logo vem a contradição exatamente porque o pais tem se destacado no trabalho escravo no campo, e o agronegócio continua sendo o setor que mais submete trabalhadores à condição análoga à escravidão. Dados divulgados pela Divisão de Fiscalização para Erradicação do Trabalho Escravo (Detrae) do Ministério do Trabalho (MT) expõe um acréscimo de 37 novos empregadores na lista, sendo que, entre eles, 16 são donos de fazendas ou madeireiras, um total de 43\%. (BRASIL DE FATO, 2018).

3. Tudo - não pode ser tudo, uma vez que o alimento, condição básica de existência, é transformado em commodities e passa a ser concentrado por um pequeno número de empresas em que sete delas dominavam mundialmente o controle das sementes, e também os fertilizantes e pesticidas que se fundiram em 2017, tornando apenas quatro, perceptíveis na figura 05. 
Figura 05: Fusão das empresas que detêm o controle das sementes

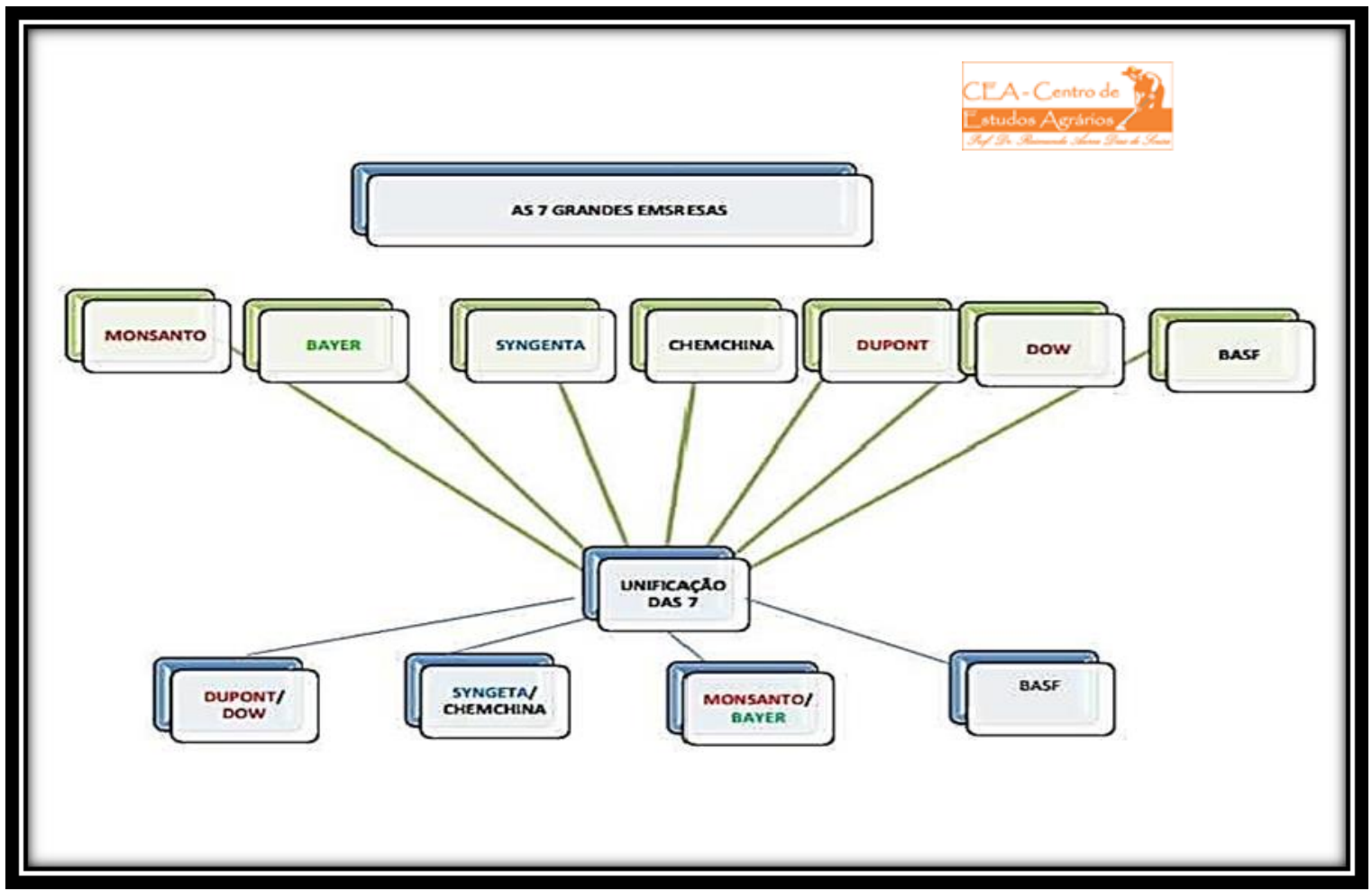

Fonte: Brasil de fato disponível em: Disponível em:

https//www.brasildefato.com.br/2018/06/08/guardiões-de-sementes-resistemao-monopolio-das-multinacionais. Acesso em 22/11/2018.

Elaborado: (CARDOSO, A. S. R.2018)

Nesse contexto a figura 05, mostra a fusão dessas empresas por meio do poder da compra. Nesse caso das sete, ficam quatro da seguinte forma: a Dupont compra a Dow, a Syngenta compra a Chimchina, Bayer com a Monsanto, e a Basf não entrou nesse tramite de compra, porém, seu poder e ação se iguala, na monopolização das sementes e principalmente da terra.

Relativo ao assunto, Oliveira (2016, p. 7) ressalta:

Que dois processos monopolistas comandavam e comandam a produção agrícola mundial. De um lado está a territorialização dos monopólios e a monopolização do território Estas empresas monopolistas do setor de grãos, atuam como players no mercado futuro das bolsas de mercadorias do mundo, e, muitas vezes têm também, o controle igualmente monopolista da produção dos agrotóxicos e dos fertilizantes.

No momento em que o Agro se diz tudo, nega outras formas de produzir no campo como é o caso da agricultura familiar e camponesa em que a terra 
tem finalidades que se opõem e resistem ao negócio controlado por grandes corporações no campo.

\section{Considerações Finais}

Quando, a partir de 2015, evidencia-se diversas propagandas envolvendo os cultivos, a pecúaria e as formas de produção no campo, destacando que tudo é AGRO, portanto, a indústria e a riqueza no Brasil, imagina-se que não há outra forma de produção no campo, justamente porque ele é vendido como riqueza sem considerar que são os trabalhadores que a produzem e eles é que deveriam ser seus proprietarios e não aqueles que não trabalham.

A agricultor é muito mais, tem um outro significado que difere do negócio, portanto, a terra deveria ser distribuída para quem nela trabalha. De acordo com Martins (1982, p. 61), "é o trabalho que legitima a posse da terra; É nele que reside o direito de propriedade. Esse dirireito está em conflito com os pressupostos da propriedade capitalista".

Nesse entendimento, o Agro como produtor de riqueza (des)vela uma realidade que evidencia que ele apropria-se da terra e explora o trabalho, beneficiando um pequeno grupo detentor do capital. Também, necessita ser midia, porque é mercadoria, é poder, é polítiica. No congresso Nacional, manifesta-se via Frente Parlamentar da Agropecuária (FPA), mais conhecida por Bancada Ruralista, que para o período 2019-2022, possui 99 deputados e 19 senadores, respectivamente, $19,2 \%$ dos deputados e, $22,6 \%$ dos senadores, o que implica em dificuldades da não efetivação da reforma agrária para produção de alimentos agroecológicos, sem qualquer uso de agrotóxicos.

A referida Bancada, no discurso do "combate à fome" expande suas empresas, impedindo o direito sagrado do alimento - condição básica para a existência humana. Esse, deixa de ser uso e para ser commodities negociadas em bolsas de mercadorias e futuro, por isso é concentrador de terra, é monocultura e depende de agrotóxicos.

A resistência a esse marketing agressivo se manifesta na produção orgânica, nas sementes crioulas, valorizando as tradições locais, não respeitadas pelo Agro. 


\section{REFERÊNCIAS}

AGÊNCIA FIOCRUZ DE NOTÍCIAS. PL do Veneno desconsidera impactos na saúde e meio ambiente. Fonte: Disponível em: <https://agencia.fiocruz.br/pl-do-venenodesconsidera-impactos-na-saude-e-meio-ambiente> Acesso em: 21 nov 2018.

BOMBARDI, Larissa Mies. Geografia do uso de agrotóxico no Brasil. De olho nos ruralistas, 2016. Fonte: Disponível em: < https:// youtu.be/mryyklbkv5c > Acesso em 10 out 2018.

BOMBARDI, Larissa Mies. Agrotóxicos e agronegócio: arcaico e moderno se fundem no campo brasileiro. Direitos Humanos no Brasil 2012. Relatório da Rede Social de Justiça e Direitos Humanos. São Paulo, 2012. (p.1-13).

BRASIL DE FATO. Guardiões de sementes resistem ao monopólio das multinacionais. Disponível em: <https//www.brasildefato.com.br/2018/06/08/guardiões-de-sementesresistem-ao-monopolio-das-multinacionais/ > Acesso em 22 nov 2018.

CPT. Centro de Documentação D. Tomás Balduíno - Acervo CPT Nacional. Disponível em: <https://www.cptnacional.org.br/component/jdownloads/send/60-dados-2017/14074assassinatos-conflitos-no-campo-2017-cpt-assessoria-de-comunicacao?ltemid=0t /> Acesso em: 23 jun 2018

DAVIS, J. H. \& GOLDBERG, R.A. Concept of Agribusiness. Harvard University, 1957.

DELGADO, Guilherme C. A questão Agraria no Brasil, 1950 -2003. In: JACCOUD, Luciana (Org.). Questão social e políticas sociais no Brasil contemporâneo. Brasília: IPEA, 2005, p. 51-90.

ESTADÃO. Maia promete a ruralistas que trabalhará por perdão na dívida com Funrural. Fonte: Disponível em: https://economia.estadao.com.br/noticias/geral,maiapromete-a-ruralistas-que-trabalhara-por-perdao-na-divida-com-funrural,70002264758> Acesso em 21 nov 2018.

GLASS, Verena e SANTOS, Maureen (orgs). Altas do agronegócio: fatos e números sobre as corporações que controlam o que comemos. Rio de Janeiro : Fundação Heinrich Böll, 2018.

G1 AGRO. A Industria-Riqueza do Brasil. Disponível em: <https://g1.globo.com/economia/agronegocios/agro-a-industria-riqueza-do-brasil/>. Acesso em: 09 dez 2018.

IBGE. Censo agro2017. Brasil, 2017. Disponível em:

<https//censos.ibge.gov.br/agro/2017/> Acesso em: 23 nov 2018.

MARTINS, José de Souza. Expropriação e violência. São Paulo: Hucitec, 1982.

METRO JORNAL. Venda de produtos orgânicos pode ser proibida em mercados;

entenda. Fonte: Disponível em: <https://www.metrojornal.com.br/foco/2018/07/03/venda-de- 
produtos-organicos-pode-ser-proibida-em-mercados-entenda.html> Acesso em 20 nov 2018.

OLIVEIRA, Ariovaldo Umbelindo de. A mundialização da agricultura brasileira. São Paulo: Lãnde editorial,2016, Disponível em:<https://goo.gl/f8SrxR > Acesso em; 23 nov 2018

SAUER, Sérgio. Agricultura familiar versus agronegócio: a dinâmica sociopolítica do campo brasileiro. Brasília, DF : Embrapa Informação Tecnológica, 2008.

SHANIN, Teodor. Lições Camponesas. In: Campesinato e Territórios em Disputa org. Eliane Tomiasi Paulino, João Edimilson Frabrini. 1를. Ed., São Paulo: Expressão Popular: UNESP: Programa de Pós Graduação em Geografia, 2008.

SOUSA, Raimunda Áurea Dias de. O Agro-Hidronegócio no Vale do São Francisco: território de produção de riqueza e subtração da riqueza da produção. Universidade Federal de Sergipe, São Cristóvão-SE, 2013.

\section{NOTAS DE AUTOR}

\section{CONTRIBUIÇÃO DE AUTORIA}

Antônio Sidnei Ribeiro Cardoso - Conceituação, Análise formal, Investigação, Aquisição de Financiamento, Metodologia. Escrita- rascunho original.

Raimunda Áurea Dias de Sousa - Orientação direta. Escrita- revisão e edição, Aquisição de Financiamento, Participação ativa da discussão dos resultados; Revisão e aprovação da versão final do trabalho.

Leandro Cavalcanti Reis - Elaboração e produção dos gráficos, revisão e aprovação da versão final do trabalho.

\section{FINANCIAMENTO}

Antônio Sidnei Ribeiro Cardoso - foi bolsista PIBIC/CNPq/UPE no período de 2017-2018

Raimunda Áurea Dias de Sousa - professora orientadora responsável pelo envio do projeto ao $\mathrm{PIBIC/CNPq/UPE}$.

\section{CONSENTIMENTO DE USO DE IMAGEM}

Não se aplica. Imagens utilizadas são de domínio publico.

\section{APROVAÇÃO DE COMITÊ DE ÉTICA EM PESQUISA}

Não se aplica

\section{CONFLITO DE INTERESSES}

Não se aplica

\section{LICENÇA DE USO}

Este artigo está licenciado sob a Licença Creative Commons CC-BY. Com essa licença você pode compartilhar, adaptar, criar para qualquer fim, desde que atribua a autoria da obra.

\section{HISTÓRICO}

Recebido em: 01-02-2019

Aprovado em: 21-03-2019 